\title{
Review of solar PV policies, interventions and diffusion in East Africa
}

\author{
Hansen, Ulrich Elmer; Pedersen, Mathilde Brix; Nygaard, Ivan
}

\section{Published in:}

Renewable \& Sustainable Energy Reviews

Link to article, DOI:

10.1016/j.rser.2015.02.046

Publication date:

2015

Document Version

Peer reviewed version

Link back to DTU Orbit

Citation (APA):

Hansen, U. E., Pedersen, M. B., \& Nygaard, I. (2015). Review of solar PV policies, interventions and diffusion in East Africa. Renewable \& Sustainable Energy Reviews, 46, 236-248. https://doi.org/10.1016/j.rser.2015.02.046

\section{General rights}

Copyright and moral rights for the publications made accessible in the public portal are retained by the authors and/or other copyright owners and it is a condition of accessing publications that users recognise and abide by the legal requirements associated with these rights.

- Users may download and print one copy of any publication from the public portal for the purpose of private study or research.

- You may not further distribute the material or use it for any profit-making activity or commercial gain

- You may freely distribute the URL identifying the publication in the public portal 


\title{
Review of solar PV policies, interventions and diffusion in East Africa
}

\author{
By \\ Ulrich Elmer Hansen, Mathilde Brix Pedersen and Ivan Nygaard \\ UNEP Ris $\varnothing$ Centre, Department of Management Engineering, \\ Technical University of Denmark \\ uleh@dtu.dk, brix@dtu.dk, ivny@dtu.dk \\ Post print version of paper published in \\ Renewable and Sustainable Energy Reviews (2015), 46, pp.236-248. \\ doi:10.1016/j.rser.2015.02.046
}

Available at: http://dx.doi.org/10.1016/j.rser.2015.02.046

\begin{abstract}
Previous research on the diffusion of solar PV in Africa has mainly focused on solar home systems (SHS) in individual countries and thus overlooked developments in other PV market segments that have recently emerged. In contrast this paper adopts a regional perspective by reviewing developments in supportive policies, donor programs and diffusion status in all PV market segments in Kenya, Tanzania and Uganda, as well as identifying the key factors put forward in the literature to explain differences in the diffusion of SHS in these three countries. The paper finds two emerging trends: (i) a movement from donor and government-based support to market-driven diffusion of solar PV; and (ii) a transition from small-scale, off-grid systems towards mini-grids and large-scale, grid-connected solar power plants. The paper points out three generic factors that have contributed to encouraging SHS diffusion in all three countries: (i) the decline in world market prices for PV modules; (ii) the prolonged support from international donors; and (iii) conducive framework conditions provided by national governments. The paper also identifies five key factors that have been elaborated in the literature to explain the higher level of SHS diffusion in Kenya compared to Tanzania and Uganda: (i) a growing middle-class; (ii) geographical conditions; (iii) local subcomponent suppliers; (iv) local champions; and (v) business culture. Finally, the paper discusses the lack of attention in the literature given to analysing the amount, nature and timing of donor and government support across countries, processes of learning and upgrading in local PV industries and the interaction between the different explanatory factors.
\end{abstract}

\section{Key words}

Solar photovoltaic; market segments; policies; Kenya; Tanzania; Uganda 


\section{Introduction}

For a long period, the diffusion of solar photovoltaic (PV) in Africa has been promoted through government and donor-funded projects as a means to provide electricity to remote rural populations in off-grid areas. Solar PV has been considered an appropriate option in cases where grid-extension is not feasible and where other energy sources, such as biomass and hydropower, are not readily available or economically viable. Underlying the programs and projects implemented to support solar PV have been a number of perceived developmental benefits, which include improved air quality in households by reducing the use of polluting fuels for cooking, lighting and heating, better nutrition from access to refrigerators, and educational benefits from increased study time and the provision of electricity-dependent equipment in schools [1,2].

Recently the rapid and substantial decrease in the price of solar PV panels, in combination with rising oil prices, has made solar PV increasingly competitive with conventional technologies, such as diesel-fired generators, which are widely used throughout Africa [3]. Due to the foreseen business opportunities, this has led to a mushrooming of local providers of solar PV components and systems and to the establishment of solar panel assembly plants in a number of African countries [4]. Additionally, solar PV has attracted renewed interest among policy-makers, energy planning agencies and donors, which has resulted in the adoption of supportive incentives in the form of financing schemes, exemptions from VAT and import taxes, power-purchasing agreements and feedin tariffs (FITs).

Previous research undertaken on the effects of these supportive measures in terms of installed solar PV capacity have mainly focused on the diffusion of solar home systems (SHS) in individual countries, for example, in Kenya [5]. This means that there is currently only limited understanding of developments in other solar PV market segments beside SHS that have recently emerged, such as mini-grids and large-scale solar power [3]. In addition, the predominant focus in the literature on the specific conditions underlying the diffusion of SHS in the context of individual countries implies that findings are particularistic and therefore less generalizable. Hence, there is a need for broader cross-country comparisons of patterns of solar PV diffusion. As a contribution to filling this gap in the existing literature, this paper adopts a regional perspective, focusing on the diffusion of solar PV in different market segments across three countries in East Africa: Kenya, Tanzania and Uganda. To guide the analysis, the focus is on addressing three interrelated questions: (i) the current status and emerging trends concerning the diffusion of solar PV in different market segments within these countries; (ii) which donor programs and national polices have been adopted to promote the diffusion of solar PV; and (iii) what may explain the disparate patterns of solar PV diffusion in the three countries? These questions will be analysed in two steps. First, the development and current status of solar PV diffusion in the three countries and the policies and programs implemented to support different solar PV market segments will be reviewed. Secondly, the technological innovation system framework of Bergek et al. [6] will be used to identify the key factors provided in the literature to explain the different patterns of solar PV diffusion in the three countries. This analysis focuses on the SHS market segment, as this has been the dominating area of analysis in the existing research.

The paper is structured as follows. Sections 2 and 3 presents the research methods and analytical framework adopted. Section 4 provides a review of the developments and status of solar PV diffusion in Kenya and the government policies and donor programmes that have supported the different solar PV market segments. Sections 5 and 6 conduct a similar review for Tanzania and Uganda respectively. Section 7 presents a crosscutting discussion of the findings across the three countries. Section 8 provides an analysis of the key factors highlighted in the literature to explain differences in solar PV diffusion in Kenya, Tanzania and Uganda. Finally the conclusions of the paper will be presented in Section 9. 


\section{Research methods}

This paper mainly draws on empirical research published in the peer-reviewed literature and sources in the grey literature, such as donor reports, consultancy and policy documents, and occasional use of media reports, where relevant. To supplement the review, the paper includes information from interviews conducted in January 2014 with solar PV industry stakeholders in Uganda, such as local PV suppliers, industry experts, representatives of donor programs and government officials. Topics discussed during interviews included historical developments and the diffusion status of different solar PV segments, local industry and SME business development, factors encouraging and discouraging solar PV diffusion in Uganda, and the relevant political and regulatory frameworks. With respect to large-scale, grid-connected solar PV, the paper also relies on feedback on a paper on prospects for investment in large-scale solar power in Africa, which was distributed and presented orally at a recent conference in Copenhagen in June 2014. ${ }^{1}$ This allowed inputs from the presentations and discussions with stakeholders from the three countries to be incorporated. This procedure for the collection of data was used to triangulate information obtained from the documentary sources.

\section{Analytical framework}

To structure the analysis of the policies, programs and diffusion of solar PV in Kenya, Tanzania and Uganda (presented in Sections 4, 5 and 6) a distinction between five types of PV segments has been developed and presented in section 3.1 below. In addition, the technological innovation system (TIS) framework was used to structure the analysis of the key factors highlighted in the literature to explain differences in solar PV diffusion in the three countries (presented in Section 8). The operationalization of the TIS framework involved the categorisation of specific factors that were found to resonate across research papers according to the particular functions suggested by Bergek et al. [6].

\subsection{Solar PV market segments}

Solar PV systems range from the smallest pico-applications, such as solar lanterns and small mobile-phone chargers, via solar home systems (SHS) installed in private households and mini-grids at village level, to utility-scale, grid-connected plants. Therefore, although solar PV is often considered a distinct type of technology, it is clear that solar PV systems are quite different in terms of scale, capital-intensity, technological characteristics, target groups and competing technologies. Accordingly, it is crucial to distinguish between the different market segments in which these PV systems are being diffused, as these are characterized by fundamentally different dynamics. In Table 1 , a fivefold categorization of solar PV market segments is presented, which will be used to guide the subsequent review.

\footnotetext{
${ }^{1}$ Information and presentations from this seminar can be found at: http://www.unepdtu.org/PUBLICATIONS/Workshop-Presentations/Workshop-Presentations---SustainableEnergy-Investments-in-Africa
} 
Table 1. Characteristics of five different solar PV market segments

\begin{tabular}{|c|c|c|c|}
\hline Market segments & Market characteristics & $\begin{array}{l}\text { Installed } \\
\text { capacity / } \\
\text { size }\end{array}$ & Owners and buyers \\
\hline $\begin{array}{l}\text { Small pico-systems: } \\
\text { solar lanterns, LED } \\
\text { lamps, solar chargers }\end{array}$ & $\begin{array}{l}\text { Lighting and charging of batteries and } \\
\text { mobile phones in mainly non-electrified } \\
\text { areas }\end{array}$ & $1-10 W_{p}$ & $\begin{array}{l}\text { Private (over the counter) } \\
\text { consumer devices }\end{array}$ \\
\hline $\begin{array}{l}\text { Solar home systems } \\
\text { (SHS) }\end{array}$ & $\begin{array}{l}\text { Off-grid electricity demand in private homes } \\
\text { in dispersed settlements, in smaller non- } \\
\text { electrified villages and on the outskirts of } \\
\text { electrified towns and villages far from } \\
\text { existing distribution lines }\end{array}$ & $10-100 W_{p}$ & $\begin{array}{l}\text { Residential SHS (private } \\
\text { households), ESCOs }\end{array}$ \\
\hline $\begin{array}{l}\text { Stand-alone } \\
\text { 'institutional PV } \\
\text { systems' }\end{array}$ & $\begin{array}{l}\text { Institutions located in villages without grid } \\
\text { or mini-grid, or on the outskirts of grid- } \\
\text { electrified villages }\end{array}$ & $50-500 W_{p}$ & $\begin{array}{l}\text { Government/municipal } \\
\text { procurement for public } \\
\text { institutions (schools, hospitals, } \\
\text { health clinics) }\end{array}$ \\
\hline $\begin{array}{l}\text { Telecommunications } \\
\text { and tourism }\end{array}$ & $\begin{array}{l}\text { Powering telecom base receiver stations } \\
\text { (BTS), link sites, and remote tele-centres, } \\
\text { and basic electricity supply (mainly lighting) } \\
\text { for rural lodges and hotels }\end{array}$ & $0.2-15 \mathrm{KW}_{\mathrm{p}}$ & $\begin{array}{l}\text { Procurement by commercial } \\
\text { companies in the telecom and } \\
\text { tourism sectors (e.g. telecom } \\
\text { service providers, hotel owners, } \\
\text { etc.) }\end{array}$ \\
\hline $\begin{array}{l}\text { Mini-grids (e.g. hybrid } \\
\text { PV-diesel) }\end{array}$ & $\begin{array}{l}\text { Villages and towns located far from existing } \\
\text { grid }\end{array}$ & $5 \mathrm{~kW}-1 \mathrm{MW}_{\mathrm{p}}$ & $\begin{array}{l}\text { Utilities, cooperatives } \\
\text { (community-based), ESCOs } \\
\text { (village electrification projects) }\end{array}$ \\
\hline $\begin{array}{l}\text { Large-scale, grid- } \\
\text { connected PV systems }\end{array}$ & $\begin{array}{l}\text { Expansion of production capacity in existing } \\
\text { grid }\end{array}$ & $1-50 \mathrm{MW}_{\mathrm{p}}$ & $\begin{array}{l}\text { Utilities, IPPs (incl. foreign } \\
\text { investors) }\end{array}$ \\
\hline
\end{tabular}

Source: $[7,8]$.

The 'small pico-systems' segment has been excluded from what follows, as this market segment is substantially different from the other segments. While the latter comprise fixed installations based on standardized PV panels, controllers and batteries installed by skilled technicians, pico-systems are integrated products which are more similar to other appliances such as lanterns or torches and are therefore usually bought over the counter. In the description of the five market segments of interest to this paper, the focus will be on assessing the scope for public intervention by governments and donors in order to promote the development of specific market segments.

The market for solar home systems is similar to that for various types of over-the-counter consumer products, such as air-conditioning, that need to be installed by a technician, but that are readily available in specialist shops [7]. Governments and donors may provide indirect support to this mainly private market through various measures, such as i) exemption from import duties on PV components, ii) enforcing systems of product quality standards, and iii) supporting specific credit schemes to suppliers and customers.

The 'institutional PV systems' segment is different not only because of its larger scale and capital-intensity, but also because of the supporting instruments and typical interventions that are used to promote this segment. Most interventions in this segment are direct, as institutional PV systems are usually procured directly by donors or government agencies (often in combination) to provide electricity in schools or public buildings located in off-grid areas.

The 'telecommunication and tourism' market segment is characterised by PV systems procured directly by private, commercial actors in the communications technology industry (e.g. telecom service providers) and the tourism sector (e.g. hotel owners and rural entrepreneurs). These PV systems are typically installed at remotely located base transceiver stations in order to reduce operating costs or in rural lodges to cover basic lighting needs. As this segment is purely marketbased, government and donor support are limited to providing broad enabling incentives, such as general VAT and duty exemptions for PV components. 
The 'mini-grid' segment includes new hybrid PV-based plants and the hybridisation of existing, conventional diesel-fired power plants with solar PV, which are typically installed in larger towns far from the national grid [8]. Mini-grid systems can range from covering a relatively small number of households and commercial consumers to providing whole villages or groups of villages with electricity over a local distribution grid. They can be owned and operated by local cooperatives in so-called community-based systems, by national utilities or by foreign or national energy service companies (ESCOs). In some cases, mini-grids are also established in connection with cell-phone towers, factories or plantations with support from donors or governments. Rural electrification is in general heavily subsidized, either through rural electrification agencies or cross-subsidization within utilities. The scope for government and donor interventions to support PV in rural electrification can be directly by providing project development support, subsidies and finance and, more indirectly, by providing the necessary regulatory set up for operators.

Finally, the 'grid-connected' PV market segment is characterised by large-scale capitalintensive plants, which can be owned and operated by utilities and private operators, so-called independent power producers (IPPs), often involving foreign investors [3]. Government interventions to support this segment may consist of indirect measures, such as feed-in tariffs, but may also be more direct through the management of bidding rounds and contractual arrangements with operators.

\subsection{Technological innovation systems}

The technological innovation system (TIS) framework has been developed as a heuristic tool to study the conditions under which the generation, diffusion and utilisation of a specific technology unfolds under particular institutional circumstances [9]. While in principle the TIS for a specific technology is global in nature (see Carlsson and Stankiewicz [10]), this paper follows the approach adopted in Schmidt and Dabur [11] to have an increased focus on the national TIS for solar PV. The study of TIS generally proceeds by exploring two main components. The first component involves an analysis of the structural composition of the TIS around a specific technology, which focuses on the actors and organisations involved, such as firms, public agencies and end-users, the networks among these agents, and the formal and informal institutional structures involved, for example, the regulatory, political and cognitive frameworks. The second component focuses on the overall functioning of the TIS in question, which involves an analysis of the specific functions that, depending on their strength, may impede or encourage the development and diffusion of a new technology. Following the approach adopted in Tigabu et al. [12], the analysis in Section 8 makes use of the functional typology developed in Bergek et al. [6], which comprises a list of seven functions that determine the ability of a specific TIS to promote the diffusion and adoption of new technologies (see Table 2 below). 
Table 2. Functional components of technological innovation systems

\begin{tabular}{|l|l|}
\hline Functions & Description \\
\hline Knowledge development and diffusion & $\begin{array}{l}\text { The generation of breadth and depth of the knowledge base of the TIS, and the } \\
\text { diffusion and combination of knowledge }\end{array}$ \\
\hline Influence on the direction of search & $\begin{array}{l}\text { The existence of incentives/pressures (and expectations) for actors to enter the } \\
\text { TIS, and to direct their activities towards certain parts within the TIS (e.g. } \\
\text { technologies, applications, or markets) }\end{array}$ \\
\hline Entrepreneurial experimentation & $\begin{array}{l}\text { The probing into new technologies and applications, unfolding a social learning } \\
\text { process reducing uncertainty }\end{array}$ \\
\hline Market formation & $\begin{array}{l}\text { The timing, size and type of markets that have actually formed, including } \\
\text { customer demand and user preferences }\end{array}$ \\
\hline Legitimation & $\begin{array}{l}\text { The extent to which the new technology and its proponents are considered } \\
\text { appropriate and desirable by relevant actors in different parts of the TIS to } \\
\text { acquire political strength. }\end{array}$ \\
\hline Resource Mobilization & $\begin{array}{l}\text { The availability of human resources (e.g. skilled labour), physical resources (e.g. } \\
\text { infrastructure, material, etc.), financial resources (e.g. investments, venture } \\
\text { capital, subsidies, etc.) and complimentary products and services }\end{array}$ \\
\hline Development of positive externalities & $\begin{array}{l}\text { The interconnectedness between different parts of the TIS, and between the TIS } \\
\text { and the external environment, in fulfilling the other functions }\end{array}$ \\
\hline
\end{tabular}

Source: $[9,6,13])$.

\section{Kenya}

\subsection{Development and status for different PV segments}

While Kenya today boasts a solar market that is one of the most mature and wellestablished in Africa, its origins date back to the 1970s, when the Kenyan government started to use solar energy as a means to power signalling and broadcasting installations in remote areas. Subsequently, from the 1980s onwards, international donors and NGOs began to play a greater role, as they included solar in their development programmes by means of workshops, training programmes and demonstration projects that contributed to generating a demand for PV in Kenya $[13,14]$. While government and donor programmes have continued to play an important role in promoting PV in the country, this support has gradually been phased out in parallel with the establishment of a private market, which slowly started to emerge during the 1980 s with the first established suppliers of solar equipment to customers in rural areas [16].

During the 1980s and 1990s, this private market grew rapidly along with a continued reduction in PV system prices, which led to a genuine boom period during the late 1990s [17]. Thus, while overall installed PV capacity was estimated at around $1.5 \mathrm{MW}$ peak $\left(\mathrm{MW}_{\mathrm{p}}\right)$ in the early $1990 \mathrm{~s}$, by 2000 it had more than doubled to approximately $3.9 \mathrm{MW}_{\mathrm{p}}[17,18]$. A decade later, total installed capacity had reached between 8 and $10 \mathrm{MW}_{\mathrm{p}}$ of installed capacity according to the comprehensive market review undertaken by GTZ in Kenya in 2009 [17]. Although information about subsequent developments in installed PV capacity has been sporadic, Ramboll [20] estimated that at least 320,000 SHS were in operation in 2010. Similarly, Meza [21] claimed a figure of $16 \mathrm{MW}_{\mathrm{p}}$ for 2012, and Tobias Cossen of GIZ a figure of $20 \mathrm{MW}_{\mathrm{p}}$ in November 2013 [22].

During the initial development phase in the late 1980s and early 1990s, the Kenyan solar PV market was dominated by donor-funded projects and the public procurement of systems to provide electricity to schools, health centres, missions and other social institutions in rural off-grid areas. According to Acker and Kammen [14], this 'institutional PV system' market segment amounted to approximately two thirds of total installed capacity in the early 1990s, when it was overtaken by the increasing market for residential SHS, which, according to Ondraczek [19], amounted to around $75 \%$ of installed capacity in 2000. In 2009 the installed capacity of residential SHS and institutional market segments was about $80 \%$ and $20 \%$ respectively (corresponding respectively to $6-8 \mathrm{MW}_{\mathrm{p}}$ and $2 \mathrm{MW}_{\mathrm{p}}$ of the total installed capacity of 8-10 $\mathrm{MW}_{\mathrm{p}}$ ) [17]. Recently, annual sales of solar PV systems have 
reached 1-2 $\mathrm{MW}_{\mathrm{p}}$, with much of the market dynamic stemming from demand for residential SHS [19]. In 2009, installed capacity in the telecommunications and tourism segment was estimated at $150 \mathrm{~kW}_{p}$, a relative low share of total installed PV capacity in Kenya [17]. The emergence of new mini-grid PV installations in rural Kenya has appeared to be limited until now [4], although Muchunku [23] estimated that six out of twelve existing diesel mini-grids in the country (with a total installed diesel-based generating capacity of 7.7MW) had been hybridized with PV (see also Hankins [24]). Four grid-connected PV plants have evidently been installed in Kenya so far: one plant in the UN compound in Nairobi with an installed capacity of $575 \mathrm{~kW}_{\mathrm{p}}$, another at the SOS Children's village in Nairobi with an installed capacity of $60 \mathrm{~kW}_{\mathrm{p}}[24,4]$, a third, $72 \mathrm{~kW}_{\mathrm{p}}$ system installed at a flower farm in central Kenya in early 2013 [22], and a fourth, $1 \mathrm{MW}_{\mathrm{p}}$ plant at a tea-processing facility, also installed in 2013. While the first two plants were financed mainly by international donors, the other two were financed by the industrial users themselves and delivered by the Kenyan-based company East African Solar Ltd. under turnkey contracts [26]. ${ }^{2}$

\subsection{Policies and donor programmes supporting different PV market segments in Kenya}

a) Solar home systems (SHS)

According to Hankins [15], the Kenyan government has generally adopted a 'light touch' regulatory approach to supporting the development of a private (i.e. household) market for SHS and thus resorted mainly to the use of indirect policy measures. This has primarily taken the form of exemption from value-added tax (VAT) and duties on imported PV products and components, enacted in 1986. Government targets or legislation designed specifically to increase the uptake of SHS have been absent $[16,26,27]$, as market development in Kenya has been driven mainly by commercial and private-market actors [14]. Nevertheless, a number of international donor organisations have been active in supporting the development of the private SHS market segment in Kenya through various programmes, especially in the period from 1995 to 2007 [29]. Of particular importance was the photovoltaic market transformation initiative (PVMTI) implemented by the World Bank in the period 1998-2008, with a total budget of US\$ 5 million. By providing favourable loans to consumers and suppliers of SHS in Kenya, PVMTI was instrumental in improving financial conditions for the diffusion of SHS. The German development organisation $\mathrm{GTZ}^{3}$ has also been active in supporting the diffusion of SHS in Kenya in many cases, with the objective of exploiting commercial opportunities for German suppliers of SHS [17].

\section{b) Stand-alone 'institutional PV systems'}

The development of the institutional PV market segment has been led by various international donors and development agencies, particularly during the initial stage of market development during the 1980 s $[29,28]$. These have focused mainly on providing lighting to schools through individual projects in rural areas. Kenya also has many active NGOs and missions providing services in the remote off-grid parts of the country, such as solar PV-powered water pumps, and vaccine refrigerators in health clinics. More recently, the government's so-called Solar Energy Development project aims to electrify 500 rural institutions through solar PV systems [31], and the National Energy Policy has set out to install solar PV systems in $50 \%$ of all the remaining public facilities in the off-grid areas by 2016 [32].

\footnotetext{
${ }^{2}$ See also http://www.eastafricansolar.com/

${ }^{3}$ Now GIZ.
} 


\section{c) Telecommunications and tourism}

The information and communications technology (ICT) sector, especially mobile telephony, has grown substantially in Kenya since 2002. Indeed, subscriber growth in the period from June 2007 to June 2008 alone reached $39 \%$, a trend that has continued since. This has led to a substantial expansion of base transceiver stations (BTS) in rural areas, and a number of telecom operators have begun implementing PV systems at these sites $[16,18]$. PV installations have also been increasing in the tourism sector, mainly to covering lighting and basic electricity needs in rural lodges and tented camps [29].

\section{d) Mini-grids (e.g. hybrid PV-diesel)}

Support for the establishment of mini-grids, either fully powered by solar PV alone or in combination with diesel generators, is a fairly recent development in Kenya [22]. The Kenyan government's rural electrification master plan from 2008 supports the retrofitting of existing dieselbased decentralised power stations into hybrid schemes with solar PV, which, according to Gichungi [33], is motivated by a wish to reduce operating costs (see also Moner-Girona et al. [17]). International donors have also been supporting PV-powered mini-grids in Kenya, most importantly the World Bank's Scaling-Up Renewable Energy Program (SREP), which aims to install $3 \mathrm{MW}$ of (PV and wind) in hybrid with the existing diesel generators in 12 isolated grids with a total installed capacity of $11 \mathrm{MW}$ [34]. Likewise, through the so-called Energy for Development (E4D) project, the Department of International Development (DFID) in the UK has supported PV-powered community based mini-grids in Kenya [35]. The revision of the FiT tariff scheme in 2012 (see below) introduced a FiT of 0.20 USD/kWh for mini-grids [36]. Within the past one and a half years a few private companies have started implementing village-level mini-grids based on a commercial business model. However, installed capacity within this category is at this stage still low (approx. $100 \mathrm{KW}$ ).

\section{e) Large-scale, grid-connected PV systems}

In 2008, the Kenyan government launched a feed-in tariff (FIT) policy to support gridconnected renewable energy, which was later revised in 2010 to include solar PV and again in 2012 to adjust tariff prices [36]. The current FiT price for grid-connected solar PV is $0.12 \mathrm{USD} / \mathrm{kWh}$ (ibid.). Given the increasing demand for energy in Kenya, fuelled mainly by rapid economic growth, a main objective of the FIT policy is to contribute to expanding capacity in the existing grid in order to maintain an adequate reserve margin and ensure security of electricity supply. According to Willis [37], 25 projects with a total installed capacity of $750 \mathrm{MW}$ are currently proceeding from the initial feasibility stage towards the power purchasing agreement stage under the FIT policy. Although this would seem to suggest substantial interest from private investors, in 2013 some observers are stressing that PV tariff rates are too low to attract domestic and foreign investors $[20,21]$. Nonetheless the Government of Kenya has high expectations regarding the future of grid-connected PV in Kenya. According to the National Energy Policy [32], Kenya expects installed capacity to grow as follows: to $100 \mathrm{MW}_{\mathrm{p}}$ by 2016, $200 \mathrm{MW}_{\mathrm{p}}$ by 2022 and $500 \mathrm{MW}_{\mathrm{p}}$ by 2030. Recently, foreign investors have apparently being entering the Kenyan market for grid-connected plants. According to Finkelstein [38] and Woods [39], two plants of $50 \mathrm{MWp}$ are currently in advanced stages of planning. 


\section{Tanzania}

\subsection{Development and status for different PV segments}

Tanzania, like Kenya, started using PV for the government-financed electrification of rural institutions, such as schools, churches and health centres, in the 1970s. Since then the PV market has continued to be dominated by government procurement projects and donor-supported programmes for such rural institutions. A consumer market for PV in Tanzania started to evolve from the late 1990s and early 2000s onwards, mainly as a result of the expansion of the solar PV industry in Kenya into Tanzania [40]. The development of this private market for solar PV evolved from an installed capacity of $300 \mathrm{~kW}_{\mathrm{p}}$ in the late 1990s to approximately $1.2 \mathrm{MW}_{\mathrm{p}}$ in 2003 to around 3-4 $\mathrm{MW}_{\mathrm{p}}$ in 2009 [19] and to more than $5 \mathrm{MW}_{\mathrm{p}}$ in 2012 [41]. During this development, annual sales grew from $70 \mathrm{~kW}_{\mathrm{p}}$ in 2002 to 200-300 kW between 2003 and 2007. Recently, Meza [41] has estimated sales of solar energy to have reached $2 \mathrm{MW}_{\mathrm{p}}$ in 2011, and they are thought to have been higher in 2012 and 2013 due to large-scale project initiatives and continued SHS demand.

SHS and small-scale commercial systems make up around $75 \%$ of installed capacity in Tanzania and are hence the biggest segment in the country's solar market [19]. This capacity was installed in an estimated 40,000 SHS by the end of 2008, with annual sales of at least $4000-8000$ systems, which, according to Hankins et al. [40], translates into an annual increase of around 200$300 \mathrm{~kW}_{\mathrm{p}}$. The remaining $25 \%$ of installed PV capacity in Tanzania largely consists of institutional PV systems in schools, health centres, missions and government offices, while the telecommunications and tourism segments (and other uses of PV, such as in game parks) only play a minor role in comparison. Currently the mini-grid market segment in Tanzania is also limited, and although Ondraczek [19] claims that a few PV mini-grid installations do exist, information about these are scarce. To the authors' knowledge there are currently no grid-connected PV plants in operation in Tanzania.

\subsection{Policies and donor programmes supporting different PV market segments in Tanzania}

a) Solar home systems (SHS)

In 2005 the Tanzanian government took steps to support the SHS market segment by exempting solar systems from $20 \%$ of VAT and reducing import duties to $5 \%$ [42]. Besides this, two larger programmes have been implemented to increase demand by lowering consumer costs.

From 2007 the so-called Tanzania Energy Development and Access Project (TEDAP) (earlier known as Energizing Rural Transformation) reduced consumer costs by providing a subsidy to qualifying companies of US\$2/W $\mathrm{W}$ per sold system for systems below $100 \mathrm{~W}_{\mathrm{p}}$. TEDAP was a World Bank/GEF-funded programme implemented by REA, one objective of which was to promote SHS uptake in Tanzania. The total budget for the off-grid component was $22.5 \mathrm{Mn}$ USD [39,42]. Since 2008 REA has lowered consumer costs through the so-called PV Clusters Project, which supported private households in buying and installing SHS collectively (bulk purchasing) to reduce the overall cost. The project targeted clusters consisting of organised labour or farmers' groups with a minimum of a thousand members. These clusters engaged in annual wholesale procurements of solar PV systems through tendering, and REA provided subsidies for systems procured (20\% of the cost) [44].

Beside these demand-side interventions, international donor agencies have focused on supporting the supply side, that is, the private solar PV market actors. From 2004 to 2009, UNEP led an initiative entitled Transformation of the Rural Photovoltaic Market in Tanzania with a specific focus on using the 'private sector as a vehicle for providing basic services from PV' [45]. The programme included business and technical skills training for private-sector merchants, as well as the establishment of financing mechanisms to provide consumers with access to SHS. The SIDA /MEM Solar Energy Project was implemented in 2005-2011 with a budget of USD 3.2 million to 
provide technical, business and sales support to PV businesses, with the aim of improving the market for solar power and building up the solar industry in the country [46].

Another supply-side support project is the Developing Energy Enterprises Project East Africa (DEEP EA), a five-year initiative established in 2008 by the Global Village Energy Partnership (GVEP) focusing on micro- and small energy enterprises in Kenya, Uganda and Tanzania. DEEP EA supported the development of energy enterprises formed by, and for, rural and peri-urban entrepreneurs by assisting them with the identification of viable energy market opportunities, technology options and service structures to generate revenue and sustain businesses [46].

\section{b) Stand-alone 'institutional PV systems'}

The main driver for institutional PV systems in Tanzania is direct procurement through REA, together with international donor programmes and development organisation projects (such as TEDAP). One element of this is the Sustainable Solar Market Packages Project (SSMP), implemented by REA from 2007 and designed to establish a functioning institutional framework for commercially based service delivery for rural electrification [47]. Each SSMP arranges the supply of solar PV energy equipment with long-term maintenance contracts to rural institutions such as schools, clinics and other community facilities in a defined rural area, together with requirements and incentives for commercial sales to households in the same area. Another programme, the Transformation of the Rural Photovoltaic Market in Tanzania, resulted in the installation of solar PV systems in more than a hundred public institutions, such as health facilities and schools [45]. The programme also facilitated the inclusion of PV in the local authorities' annual budget plan in Mwanza and in three other regions: Kagera, Mara and Shinyanga.

\section{c) Telecommunications and tourism}

Although this segment only played a minor role in the solar PV market in Tanzania in 2008, Hankins et al. [40] estimated this sector to be growing substantially, mainly due to an increasing use of solar-powered base stations in mobile-phone networks and PV in eco-tourism establishments and rural tented camps and lodges.

\section{d) Mini-grids (e.g. hybrid PV-diesel)}

Through the newly established Scaling Up Renewable Energy in Low Income Countries Program (SREP) funded by the Climate Investment Funds, the government of Tanzania aims to provide electricity to 400,000 off-grid households and other consumers using renewable energy mini-grids, micro-grids and SSMP projects [48]. Further, the Ministry of Energy and Minerals (MEM) has established simplified procedures for private-sector investment in solar, wind and micro-hydro projects, including a $100 \%$ depreciation allowance in the first year of operation [46]. According to Tenenbaum et al. [49], the government of Tanzania is applying light-handed regulation for Small Power Producers (SSP). SPPs operating on an isolated mini-grid generating less than $1 \mathrm{MW}$ are required merely to register with the regulator, instead of applying for a license, which, unlike registration, entails approval by the regulator. For very small power producers (VSPPs) with an installed capacity of $100 \mathrm{~kW}$ or less, the Tanzanian regulator requires no prior regulatory review or approval of proposed retail tariffs (ibid.). On that basis, Tenenbaum et al. [49] argue that Tanzania has made more progress than any other African country in developing a comprehensive regulatory system to supporting SPPs. Moreover, TEDAP provides two types of subsidy to project developers: performance grants and matching grants [43]. For rural mini-grid projects under the performance grant, a subsidy of US\$ 500 is provided for each new connection, with a maximum amount of up to $80 \%$ of total investment costs. Matching grants include primarily training and consultancy services. Such initiatives may have contributed to spurring investment interest in mini-grids, as reflected in 
two recently announced PV-powered mini-grids to be developed by private investors under power purchasing agreements with the Tanzanian utility TANESO [41]. Private sector-led initiatives are in their infancy, with only a few operating mini-grids (<100 KW). However, in October 2014 REA announced the winners of their Lighting Rural Tanzania Competition, where half of the 20 winners where solar PV-based mini-grids [50].

\section{e) Large-scale, grid-connected PV systems}

The Ministry of Energy and Minerals (MEM) has established a framework for the development of renewable energy power projects ranging from $100 \mathrm{~kW}$ to $10 \mathrm{MW}$, which includes the introduction of standardized power purchasing agreements for wind, hydro, PV and cogeneration with standardized FITs [46]. According to Ondraczek [19], however, there are no signs that the government is intending to include solar PV in the national electricity mix in any significant way in the years to come. In the long-term plans for the energy sector and the state-owned utility's pipeline, the focus is almost exclusively on the expansion of natural gas, coal and hydro power [19]. One policy potentially supporting grid-connected solar PV is the FIT policy introduced in 2009. Tariffs are differentiated depending on whether the small power producer is connected to the main grid or to a mini-grid. In 2012 the average tariff for grid-connected electrification was $0.095 \mathrm{USD} / \mathrm{kWh}$ (152.54 TZS/kWh). For mini-grids in 2012 the tariff was $0.30 \mathrm{USD} / \mathrm{kWh}(480.50 \mathrm{TZS} / \mathrm{kWh})$. This is a common FIT for all technologies, and consequently the majority of projects currently under development and in the pipeline are mini-hydro. The lack of technology-based payment differentiation is, according to Nganga [51], one of the greatest weaknesses of Tanzania's FIT policy.

\section{Uganda}

\subsection{Development and status for different PV segments}

The PV market in Uganda started to develop from the early 1980s, and, as in Tanzania and Kenya, it was initially driven mainly by government and donor-funded programmes along with NGO projects, mainly for lighting and vaccine refrigeration in health centres [52].

The study of solar PV markets in Uganda from 2009 estimates total installed capacity to be $1.1 \mathrm{MW}_{\mathrm{p}}$, with annual sales of about $200 \mathrm{~kW}_{\mathrm{p}}$ [53]. According to the study, SHS only comprised $20 \%$ of total installed capacity $\left(300 \mathrm{~kW}_{\mathrm{p}}\right)$, while the institutional segment at the time comprised $45 \%$ of installed capacity $\left(470 \mathrm{~kW}_{\mathrm{p}}\right)$. PV applications in the institutional segment were mainly utilised in the health (e.g. rural health clinics), water (e.g. pumping systems), education (e.g. off-grid boarding schools) and local government sectors (e.g. public agency offices). The combined telecommunications and tourism segment took up the remaining $35 \%$ of installed capacity (340 $\mathrm{kW}_{\mathrm{p}}$ ). PV in this segment is mainly used for powering telecom BTS and link sites, remote telecenters and remote tourist lodges.

While the SHS segment only took up $20 \%$ of total installed capacity in 2009, this share seems to have increased substantially in the last 5 years. According to different sources, the number of installed SHS has risen from 3000 in 1999 [54], to 10,000 in 2004 [55], to 20,000 in 2007 and to 30,000 in 2012 [56]. According to an interview in 2014 with 'SolarNow', ${ }^{4}$ the largest players in the SHS market in Uganda, installed capacity increased by 12,000 SHSs in 2013 and 15,000 in 2013, raising the number of SHS to 45,000 in the latter year. This increase in SHS units sold in Uganda

\footnotetext{
${ }^{4}$ Interview with Willem Nolens, Managing Director, and Ronald Schuurhuizen, Business Development Manager, 16 January 2014.

${ }^{5}$ SolarNow alone installed 3600 SHSs in 2012 and 4500 in 2013. According to SolarNow they control about 30\% of the established market, indicating total sales of 12,000 SHSs in 2013 and 15,000 in 2013. Given that the smallest modules are rated at $50 \mathrm{~W}_{\mathrm{p}}$, this amounts to 600 and $750 \mathrm{~kW}$, in 2012 and 2013, or four times annual sales in 2009.
} 
added around 0.9 MW to installed capacity of SHS in 2009-2013 [57], reflecting very high growth after 2009.

Only a few hybrid solar PV and diesel-powered mini-grids have been installed so far in Uganda, including one at a rural boarding school in Bulyansungwe south-west of Kampala [58]. Gridconnected, utility-scale PV power plants have not been put into operation in the country.

\subsection{Policies and donor programmes supporting different PV market segments in Uganda}

a) Solar home systems (SHS)

The Ugandan government has stimulated the private market for SHS both through indirect measures, such as exemptions from import duties and VAT on PV products and components, and directly, by providing a subsidy of $5.5 \mathrm{USD} / \mathrm{W}_{\mathrm{p}}$ (with a maximum system size of $50 \mathrm{~W}_{\mathrm{p}}$ ) on solar equipment purchased by households and 4 USD/ $W_{p}$ (for systems below $500 \mathrm{~W}$ ) for businesses and institutions [53]. The subsidy was funded partly by the World Bank's Energy for Rural Transformation (ERT) programme and implemented by the Rural Electrification Agency in Uganda in the period 2002-2013 (in two phases between 2002-2009 and 2009-2013) [59]. ERT also aimed at stimulating the SHS market by reducing costs for end-users through rural-based micro-financing institutes and by providing business start-up support and technical training to PV suppliers. Despite high ambitions at the outset of the programme, only 7,000 of the 80,000 initially planned PV installations had actually been installed when the programme was terminated [60]. A precursor of the ERT programme was the so-called Uganda Photovoltaic Pilot Project for Rural Electrification (UPPPRE), which was funded by the United Nations Development Programme (UNEP) and implemented in 1998-2002 [61]. Similarly to ERT, UPPPREE targeted the development of the SHS market by providing finance to PV suppliers and credit guarantees to local banks so that they could provide loans at favourable conditions to end-users.

Programmes targeting the supply side were also implemented in Uganda. The so-called Promotion of Renewable Energy and Energy Efficiency Programme (PREEEP), funded by GTZ during the period 2007-2011, was aimed at strengthening the SHS market segment by supporting Kampalabased solar companies with branches or agents in rural areas, local solar dealers and micro-finance institutions [62]. A similar project entitled Providing Access to Energy in Northern Uganda (PAMENU) provided training to local technicians and supported local PV suppliers. This project was also implemented by GTZ during 2008-2011 [63].

\section{b) Stand-alone 'institutional PV systems'}

According to Hankins et al. [53], the ERT programme has been the main driver behind most of the direct public procurements of PV systems in the institutional market segment in Uganda. However, other international aid programmes and NGOs have also targeted the institutional PV market segment. For example, the PREEEP programme mentioned above was specifically aimed at electrifying government institutions (such as health centres, boarding schools, vocational training centres and local government offices) with solar PV systems by providing an $80 \%$ subsidy for the procurement of a PV system, the institution being responsible for providing the remaining 20\% [64]. This segment is therefore still strongly influenced by donor support, although this support is channelled through the Ugandan rural electrification agency.

\section{c) Telecommunications and tourism}

The market for PV systems in the telecommunications and tourism sector in Uganda has rapidly increased during the past decade and comprises a relatively large share of the country's total installed PV capacity. Driven mainly by an increase in the use of mobile phones in Uganda, the 
telecommunications sector has grown rapidly, resulting in a substantial increase in national coverage through the widespread establishment of base transceiver stations (BTS) and link sites in rural areas [53]. As most of these BTS facilities operate on diesel-based generators, PV has been implemented to reducing operating costs for telecom operators at these rural sites. To support this development further, in $2012 \mathrm{GIZ}$ launched a programme entitled 'develoPPP.de' aimed at supplying telecommunication masts with PV and at the same time electrifying off-grid villages close to the masts. The project, which has a scope of 250 masts, is being carried out in partnership with a German supplier of solar systems, one of the telecompanies in the country and GIZ [65]. ${ }^{6}$ In the tourism sector, PV systems have mainly been implemented to provide basic electricity supply (mainly lighting) for remotely located lodges and hotels.

\section{d) Mini-grids (e.g. hybrid PV-diesel)}

Through the ERT programme, the rural electrification agency in Uganda has promoted the establishment of isolated mini-grids (including PV), for example, by providing investment subsidies to investors [53]. The Rural Electrification Strategy Plan (RESP) from 2012 (covering 2013-2022) also specifically prioritises rural electrification through PV-powered mini-grids and has set a goal of reaching 140,000 additional off-grid installations of solar PV systems and mini-grid distribution service connections in 2022 [60]. Beside this, a recently announced agreement with the East African Chamber of Commerce indicated that foreign investors are also becoming interested in developing mini-grids in Uganda [66], though only a few have been installed so far. These include four set up in connection with the telecommunication masts described above and a PV-powered mini-grid financed by Together: Assistance for Uganda, a German aid organisation [58].

\section{e) Large-scale, grid-connected PV systems}

Under the Renewable Energy Policy adopted in 2007, the Ugandan government introduced the first phase of the Renewable Energy Feed-in tariff (REFIT) programme to encourage gridconnected bagasse co-generation and hydropower plants. A second phase of the REFIT programme, implemented in January 2011, introduced a PV tariff rate at 0.362 US\$/kWh (for systems below 2 $\mathrm{MW}_{\mathrm{p}}$ ), along with changes in tariff rates for the other eligible technologies under the programme. Later, in 2012, PV was removed from the REFIT programme after a tariff revision had identified that the drop in PV system prices was deemed to have made large-scale, grid-connected PV plants competitive without subsidies [67]. This led to a greater focus within the government on tendering and soliciting bids from private investors to develop grid-connected PV systems. To meet this demand, the so-called GET FIT programme introduced in 2013 established a special window for support to an auction process for grid-connected PV. Under this reverse bidding process, selected developers will receive a premium payment to bridge the gap between a predetermined tariff set by the Ugandan Electricity Regulatory Authority and their own offers [68]. The funds for the GET FIT programme are being made available from a number of international development organisations. As of June 2014, 9 companies were prequalified for the first bidding round for 4 plants of each $5 \mathrm{MW}_{\mathrm{p}}$. The deadline for bids was fixed at 8 August 2014, and the plants are expected to be in operation by mid-2015. ${ }^{7}$ Furthermore, a feasibility study is being completed for a $50 \mathrm{MWp}$ plant. Negotiations about the terms of a power purchasing agreement are awaiting the outcome of the bidding round mentioned above. ${ }^{8}$ Further, according to the press, in late 2013 a memorandum of understanding (MoU) was signed between the Government of Uganda and a private company for building further capacity of $500 \mathrm{MW}_{\mathrm{p}}[66]$.

\footnotetext{
${ }^{6}$ Four of these installations were in operation in January 2014.

${ }^{7}$ Personal communication with René Meyer, consultant for KfW/GET-FIT Uganda, 25.06.14.

${ }^{8}$ Personal communication with Benon Mutambo, Energy Regulatory Authority, 25.06.14.
} 


\section{Cross-country discussion of developments in PV market segments}

It is evident that Kenya has taken a lead position in terms of total installed solar PV capacity compared to Tanzania and Uganda. As the market in Kenya started earlier, it seems that the subsequent development of PV markets in Tanzania and Uganda was influenced greatly by a gradual expansion of PV suppliers into neighbouring countries and by the spilling over of policy experiences from Kenya. While Tanzania and Uganda seem to be rapidly catching up, Kenya will most likely remain at the forefront in terms of solar PV diffusion for some time to come.

It was found that SHS play a major role in Kenya and Tanzania, currently accounting for around $80 \%$ and $75 \%$ of total installed capacity respectively. In Uganda, in 2009 SHS accounted for around $20 \%$ of installed capacity, but this share has increased considerably recently. This market segment is generally encouraged by a growing demand from private households with increasing purchasing power, but it has also been supported through VAT and import duty exemptions for imported PV components and various government and donor programmes. The institutional PV segment also accounts for a large share of total installed PV capacity in all three countries, especially Tanzania and Uganda, and has mostly been driven by direct government and donor procurement of PV systems for rural schools, health clinics and public buildings. The telecommunications and tourism segment is expected to increase in all three countries, but while this segment is relatively large in Uganda, it seems to play a smaller role in Kenya and Tanzania. While the market for PVpowered mini-grids currently only comprises a limited number of installations, this is expected to increase in the future, as is reflected in the increasing number of planned mini-grids in all three countries. Similarly, a growing number of grid-connected PV plants are currently in the pipeline and have yet to materialize.

Two interesting trends are apparent from the above. The first is a movement from donorsupported initiatives towards commercially based market development. From PV being mainly a small niche for government and donor procurement, it has increasingly become a viable alternative for consumers and private investors across PV market segments. Not only has the commercial part of the SHS market segment gained an increasing share of total installed capacity in all three countries, private investors are also playing a bigger role in the other segments, such as telecoms operators and foreign IPP investors. The second trend is the movement that is currently taking place from off-grid to mini-grids and large-scale, grid-connected PV plants. Whereas the off-grid market for SHS and institutional systems is dominated by small-scale systems for individual consumers or a relative small community, the increasing focus on mini-grids and grid-connected plants comprises a significant increase in the scale and reach of PV installations.

\section{Key factors put forward to explain differences in the diffusion of solar PV}

This section explores the generic aspects that are conducive to the diffusion of solar PV, as well as examining the main underlying reasons for the different levels of solar PV diffusion in Kenya, Tanzania and Uganda, as illuminated in the literature. The aim is not to provide a comprehensive explanation of this highly complex issue, but rather to draw out some of the key factors that resonate across papers. This discussion focuses mainly on the diffusion of SHS because the literature has concentrated on this PV segment and because SHS has the dominant share of installed capacity in Kenya and Tanzania, and increasingly also in Uganda.

\subsection{Generic aspects conducive to the diffusion of solar PV in all countries}

The main generic aspects emanating from the literature fall within the TIS functions i) influence on the direction of search, and ii) resource mobilization. These are discussed in further detail below. 


\section{(i) Influence on the direction of search}

Underlying many government and donor initiatives over time to stimulate PV markets has been a continuous expectation that module prices would be reduced and thus enable PV to compete with conventional technologies. Often based on so-called learning-curve projections and actual prices, in some cases this understanding has led to over-optimistic goals to be set regarding what can realistically be achieved from policies and interventions. In the literature, it is evident that the price reduction in PV modules that has occurred, especially since the 1990s, was ascribed a key role in explaining the accelerated diffusion of solar PV in the three countries. Acker and Kammen [14], for example, pointed to falling world prices for PV modules as a main reason for the growth in the Kenyan PV market. As PV module prices continued to decline from the 1990s, several papers engaged with exploring the economic feasibility of solar PV compared to traditional electricitygenerating technologies. Gullberg et al. [69], for example, demonstrated that PV generation was able to compete with diesel generation in Tanzania, while Ondraczek [18, p. 41] more explicitly stated that 'the price of equipment is perhaps the single most important factor in the growth of solar markets in Africa'. Later, Twaha et al. [70] concluded that grid-connected solar PV had greater feasibility than diesel as a source of electricity in Uganda. In a similar vein, Ondraczek [20] recently found that the price level for grid-connected PV was competitive with diesel generators and gas turbines in Kenya, a finding the author contrasted with the prevailing understanding in the donor community and many African country governments that PV is suited only to remote off-grid and small-scale applications. These analyses showed the increasing competitiveness of PV, especially in the period since 2009, when the PV module price per watt has been drastically reduced.

\section{(ii) Resource mobilization}

It is widely recognised in the literature that international donor programmes have been a key driver in stimulating solar PV uptake in all three countries examined, primarily through support to the institutional PV segment [5]. Various papers describe such donor-funded projects aimed at electrifying social institutions in rural areas. Kivaisi [71], for example, investigated a PV project designed to provide power to key functions in a large village in Tanzania, such as a school, a mosque and a health centre (see also Hogarth [72]). In their analysis of the development of the Kenyan PV market, Hankins [14, p. 88] highlighted the importance of donor interventions by stating that 'not only did their funding create a demand for PV that allowed the private market subsequently to develop, but the donor agencies supported workshops, training and demonstration projects as well [which] played a vital role in educating the first Kenyan solar technicians, sparking an initial interest among Kenyan consumers, and proving the viability of the technology in Kenya's conditions'. Hence donor programmes provided direct financial resources to promote PV market development, but also contributed to creating the supporting industry and supply-side conditions for this [73].

The literature has also identified government support to promote PV in all three countries as important for promoting solar PV uptake. Eliah and Louineau [53, p1], for example, stressed that the historical increase in the diffusion of solar PV in Uganda was accounted for mainly by 'conducive regulatory policies that encourage investment and trade in the solar sector [and] government projects that specifically promote the use of solar in rural electrification'. This is similar to Kenya and Tanzania, and in all three countries governments have stimulated the diffusion of solar PV indirectly through feed-in-tariff systems, subsidies, and exemptions from import duties and VAT on PV components, as well as directly via public procurement projects. Some of these changes in government support may be linked to donor support, as many donor programs directly aim at influencing policy through capacity-building and providing technical support to develop specific policy measures and legal frameworks such as FIT. 
In summary, three main generic aspects seem to have been conducive to the diffusion of solar PV in all three countries: i) the decline in world market prices for crystalline silicon-based PV modules; ii) the substantive and prolonged support for solar PV from international donors; and iii) the conducive framework conditions provided by national governments. The decline in world market prices influenced the direction of search, while support from donors and governments mobilised human, financial and technical resources for project developers, public agencies and PV system suppliers.

\subsection{Specific factors explaining the relatively more advanced position of Kenya}

While the broad trends mentioned above are common to all three countries, other factors have been used to explain the relatively more advanced level of solar PV diffusion in Kenya compared to Tanzania and Uganda. The main aspects in this regard emanating from the literature falls within the TIS functions i) market formation, ii) resource mobilization and iii) entrepreneurial experimentation. These are discussed further below.

\section{(i) Market formation}

An often repeated explanation for the growth of the SHS market segment in Kenya is the general rise of an affluent rural middle class from around the 1990s, which increasingly demanded electricity to power televisions, radios, cell phones and other modern electrical appliances $[18,72]$. According to Jacobson [74], the increasing incomes from tea-growing were particularly important in improving the purchasing power of these rural customers. Indeed, Moner-Girona et al. [17, p. 2] state that the development of the SHS market segment was mainly attributable to 'high incomes among farmers (coffee, tea, horticulture), rural teachers, civil servants and businesses with a strong demand for consumer electronics (TV's, radios, cell phones)'. Consequently, the business model of many PV system suppliers in Kenya was to target this growing rural middle class that lacked access to electricity [30]. Further, Bailis et al. [15, p92] argued that, 'most buyers are rural, middle-class households that lack confidence that the power grid will be extended, are knowledgeable about photovoltaic system performance, and want to make existing battery systems less maintenance intensive. Local entrepreneurs have played a key role in the process by aggressively moving photovoltaic systems to market and by downsizing the product to the needs of the lower-income market'. This would indicate that, besides the effects of the demand from the rural middle class, the lack of prospects for grid connection was an important factor for customers in deciding to purchase SHS. At an early point in the market's development, Hankins [14, p. 90] stressed that 'an enormous demand for electricity in rural areas has gone unsatisfied because they cannot count on grid connection [and so] rural households have increasingly turned to photovoltaics to meet their electrification needs'. More recently, Kivaisi [70, p. 416] also stressed that 'a major characteristic that probably helps to explain the high adoption rate of PV systems in rural Kenya is the slow pace of the grid extension', which the author associates with the ineffective rural electrification programme in Kenya.

\section{(ii) Resource mobilization}

A number of papers employ a geographical explanation for the disparate patterns of SHS diffusion in Kenya, Tanzania and Uganda. Ondraczek [19], for example, argues that the Tanzanian population is more geographically spread compared to Kenya, where a majority of the population is concentrated in the central and western parts of the country $[39,74]$. Coupled with a relatively welldeveloped transport infrastructure in terms of road and rail links, establishing effective distribution channels and a PV supplier network has therefore been easier in Kenya. This is reflected by Woods $[38$, p. 3], who points out that 'distribution linkages are poorly established across Tanzania, partly 
due to the geographical size of the country [and] the geographical distance between players [being] a major barrier to the development of the market'. Byrne [30] also points to the geographical proximity between the PV industry, which is concentrated mainly in Nairobi, and market demand, as the customers, in living mainly on the southern and eastern sides of Mount Kenya, were located relatively close to the suppliers. Indeed, Ondraczek [19] considers the close distance between the PV supplier industry and the end-market to be a key explanation for the initial growth of the commercial SHS market in Kenya during the 1990s.

Hankins [14, p. 88] highlights the development of a local battery supplier industry during the 1990s in Kenya as a key factor in accelerating the diffusion of solar PV and in particular emphasizes that 'technical modifications, known and utilized in the manufacture of batteries for other applications for years, improved PV system performance'. This points towards cross-fertilisation of the technical development mainly of car batteries to suit PV systems and thus a fruitful interaction between two emerging industries in Kenya. This is supported by Moner-Girona et al. [18], who stress that increases in the local availability of components such as batteries, wiring, circuitry and charge controllers in Kenya led to substantial decreases in PV system costs, as this reduced the need for imports, which contributed to stimulating solar PV diffusion. Similarly, Moner-Girona et al. [17, p. 2] stress that 'the successful development of the household and small commercial system markets is attributable to the availability of balance of systems components [and] local battery manufacturing'. Finally, Ondraczek [19, p. 409] too highlights that 'along with South Africa, Kenya is therefore the only African country with a sizable production capacity for solar modules, balance of system (BOS) components and lead acid batteries, and serves not only as an import hub, but also as a manufacturing centre for the wider region'.

\section{(iii) Entrepreneurial experimentation}

Various papers have accentuated the importance of particular individuals who have worked to support the overall development of the PV market in Kenya. Two expatriate engineers in particular - Harold Burris and Mark Hankins, both ex-Peace Corps volunteers - have been widely cited as playing a key role in the initial development of the SHS market segment in Kenya (see e.g. Duke et al. [5]). Indeed, Hankins [14, p. 87] states that 'the private market's genesis may be roughly dated as 1984. That year, an American engineer, Harold Burris, founded a small company called Solar Shamba'. According to Kivaisi [70, p. 417], 'Burris trained a group of about a dozen local technicians to market and install PV lighting systems. By reaching out to the high-income households on the southern and eastern sides of Mount Kenya, the rich white coffee and tea farms [and] Burris' successes attracted other local entrepreneurial groups and individuals to join the rural PV market'. After meeting Mark Hankins in the early 1980s, these two individuals provided training to local technicians in PV systems, as well as preparing various PV-related technical tools and guide books and broader consultancy and promotional activities. Through Burris's company, they also engaged in a number of demonstration projects showcasing PV systems in Kenya, which, according to Byrne [30], was instrumental in attracting interest from donors and the Kenyan government.

Ondraczek [19, p. 414] ascribed a generally enabling business environment in Kenya a key role in stimulating the SHS market by pointing to 'a strong entrepreneurial culture in Kenya and openness to foreign investors and business practices/ideas', while also deploring that 'the lack of entrepreneurs hindered the emergence of successful solar companies in Tanzania during the 1980s and 1990s'. Similarly, Byrne [29, p. 207] highlighted that the 'opportunistic behaviour of entrepreneurs once the demand had been demonstrated' was a key to promoting market development, thus pointing to the widespread opportunism and risk willingness of local firms in Kenya to enter the PV market during its initial development (see also Hankins et al. [17]). These findings link the emergence of a PV market mainly with the existence of a particularly dynamic and entrepreneurial business attitude in Kenya compared to Tanzania and Uganda. 
In conclusion, five key points have been identified in the literature as primary explanations for differences in the diffusion of solar PV. The first factor identified is the importance of the growing middle class in Kenya. The second and third factors are the favourable geographical conditions and the existence of a local sub-component supplier base, which are related to mobilizing resources in the innovation system. The fourth and the fifth factors are the importance of local champions and the of a vibrant business culture in Kenya, which relates to the conditions for entrepreneurial experimentation.

\subsection{Crosscutting discussion of findings and gaps in the literature}

The discussion presented above gives rise to a number of reflections about the explanations provided in the literature to account for the generic factors encouraging SHS diffusion and for the reasons behind differences in the levels of SHS diffusion in the three countries. On the basis of the TIS framework, the following will point out elements missing in the existing literature and sketch out areas of further research.

It seems reasonable to assume that the continued support from donors and governments, highlighted in Section 8.1, has generally contributed to encouraging solar PV diffusion in all three countries. However, previous research has paid limited attention to addressing whether differences in the amount, nature and timing of the technical, human and financial resources provided over time may help to explain differences in solar PV uptake across the three countries. This analysis would be interesting in order to increase the understanding of the effectiveness of different instruments and measures to creating an enabling environment for the diffusion of solar PV.

Existing research has only addressed the 'knowledge development and diffusion' functions to a limited extent, even though these are key elements of interactive learning, knowledge creation networks and technology development in TIS (see, however, Byrne [30]). This means that there is currently a limited understanding of how local learning, the development of technological capability and the upgrading of local solar PV SMEs have emerged as part of the accelerated diffusion of solar PV systems in these three countries. Issues that need further attention in this regard include how local entrepreneurs obtain access to PV technology and which sources and networks of learning they draw on to build technical and business competences. These issues should preferably be understood in the light of ongoing processes of incremental learning in the local PV industry, which relies less on formal R\&D and more on trial and error and gradual experimentation.

A related issue that has also received little attention so far in the literature concerns the dynamic interaction between different TIS functions. The existing literature seem to focus more on the identification of distinctive, individual factors than on how the interaction among these factors has influenced the diffusion of solar PV in the three countries. For example, it is evident that geographical proximity between supply and demand provided a conducive infrastructure that encouraged solar PV diffusion in Kenya. Yet, it is less clear whether and how this 'resource mobilisation' function was conducive to facilitating the cross-sharing of experiences in the PV industry and hence contributed positively to the 'knowledge development and diffusion' function by facilitating learning through local labour turnover, imitation and knowledge sharing.

In addition to these three missing elements, the existing explanations provided in the literature to account for differences in the level of SHS diffusion in the three countries identified in this paper may also need further analysis. For example, concerning the explanations stressing the existence of a local sub-component supplier base in Kenya, an interesting analytical endeavor may be to address in greater detail the conditions under which the local production of PV components may be established in the first place. An interesting area for further research may involve addressing the barriers to entry for establishing local PV module assembly production lines and how and why local industries may diversify into new branches, as in the case of the Kenyan battery industry. Similarly, it would be interesting to analyse in greater detail the role local champions play once the commercial PV market reaches a certain scale. For example, it would seem logical that their 
influence on promoting knowledge sharing would gradually be reduced when competition in the local industry increases. With regard to explanations highlighting the growing middle class in Kenya, further research may also analyse in greater detail the importance of income relative to other influential factors, such as level of education, awareness and so-called neighbor effects (see Lay et al. [76]).

\section{Conclusion}

This paper has reviewed the development and status of different solar PV market segments in Kenya, Tanzania and Uganda and the support from donors and governments to promote different PV segments. Further, the paper has also analysed the key factors put forward in the literature to explain the disparate patterns of solar PV diffusion in the three countries.

The paper finds that, although Kenya currently has the highest (total) installed solar PV capacity, Tanzania and Uganda are rapidly catching up. The SHS market segment dominates in Kenya and Tanzania and in the past five years has also increased significantly in Uganda to comprise a larger share of total installed PV capacity. The institutional PV segment is larger in Tanzania and Uganda compared to Kenya. In all countries the telecommunications and tourism segment is increasing, as are the mini-grid and large-scale solar power segments. The paper identified two emerging trends across PV segments: a movement from donor and government-supported initiatives towards commercial-based solar PV diffusion, and a movement from off-grid to mini-grids and large-scale, grid-connected PV plants.

The review also reveals that donor programs and national policies have used a combination of direct and indirect measures to promote the diffusion of solar PV. The SHS market segment has been supported mainly through indirect measures, such as VAT and import duty exemptions for imported PV components and favourable loan and credit schemes for SHS suppliers and customers. The institutional PV segment has been supported through direct procurement of systems in rural schools and health clinics. The tourism and telecommunications segment is driven mainly by private investors. The mini-grid segment is supported by private investments, government subsidies and donor programs, while the large-scale solar power segment is driven by international investors and supportive government instruments, such as feed-in tariffs.

The TIS framework enabled the paper to identify three factors that have been stressed in the literature as encouraging the diffusion of SHS in all three countries. These include the decline in world market prices for PV modules, the prolonged support from international donors and the conducive framework conditions provided by national governments. Beyond these generic aspects, the paper pointed to the following five key factors that have been elaborated in the literature to explain the relatively higher level of SHS uptake in Kenya compared to Tanzania and Uganda: (i) a growing middle-class; (ii) geographical conditions; (iii) local sub-component suppliers; (iv) local champions; and ( $v$ ) business culture. The paper further discussed the lack of attention in the literature towards analysing the amount, nature and timing of donor and government support across countries, processes of learning and upgrading in the local PV industries, and the interactions between the different explanatory factors. These issues offer promising areas for further research, which should preferably go beyond SHS to include other emerging PV market segments, such as mini-grids and large-scale solar power. 


\section{References}

[1] IRENA, "The socio-economic benefits of Solar and Wind Energy," Internatioal Renewable Energy Agency (IRENA), 2014.

[2] World Bank, "The Welfare Impact of Rural Electrification: A Reassessment of the Costs and Benefits," 2008.

[3] U. E. Hansen, I. Nygaard, and M. B. Pedersen, "Prospects for investment in large-scale, gridconnected solar power in Africa," UNEP Risoe Centre, Copenhagen, 2014.

[4] J. Ondraczek, "The Sun Rises in the East (of Africa): A Comparison of the Development and Status of the Solar Energy Markets in Kenya and Tanzania," Working paper. University of Hamburg, Working Paper FNU-195, 2011.

[5] R. D. Duke, A. Jacobson, and D. M. Kammen, "Photovoltaic module quality in the Kenyan solar home systems market," Energy Policy, vol. 30, no. 6, pp. 477-499, May 2002.

[6] A. Bergek, S. Jacobsson, B. Carlsson, S. Lindmark, and A. Rickne, "Analyzing the functional dynamics of technological innovation systems: A scheme of analysis," Res. Policy, vol. 37, no. 3, pp. 407-429, Apr. 2008.

[7] C. Breyer, C. Werner, S. Rolland, and P. Adelmann, "Off-grid photovoltaic applications in regions of low electrification: high demand, fast financial amoritization and large market potential," in 26th European Photovoltaic Solar Energy Conference, 5-9 September 2011, Hamburg, Germany, 2011, no. September, pp. 5-9.

[8] German Energy Desk, "Target market study Tanzania: solar PV and wind power," Delegation of German Industry and Commerce in Kenya, 2013.

[9] M. P. Hekkert, R. A. A. Suurs, S. O. Negro, S. Kuhlmann, and R. E. H. M. Smits, "Functions of innovation systems: A new approach for analysing technological change," Technol. Forecast. Soc. Change, vol. 74, no. 4, pp. 413-432, May 2007.

[10] B. Carlsson and R. Stankiewicz, "On the nature, function and composition of technological systems," Evol. Econ., vol. 1, pp. 93-118, 1991.

[11] T. S. Schmidt and S. Dabur, "Explaining the diffusion of biogas in India: a new functional approach considering national borders and technology transfer," Environ. Econ. Policy Stud., vol. 16, no. 2, pp. 171-199, Mar. 2013.

[12] A. Tigabu, F. Berkhout, and P. van Beukering, "Technology innovation systems and technology diffusion: Adoption of bio-digestion in an emerging innovation system in Rwanda," Technol. Forecast. Soc. Change, vol. In Press, Oct. 2013.

[13] M. Hekkert, S. Negro, G. Heimeriks, and R. Harmsen, "Technological Innovation System Analysis," no. November, 2011.

[14] R. H. Acker and D. M. Kammen, "The quiet (energy ) revolution: analysing the dissemination of photovoltaic power systems in Kenya," Energy Policy, vol. 24, no. 1, pp. 81-111, 1996. 
[15] M. Hankins, "A case study on private provision of photovoltaic systems in Kenya," in Energy Services for the World's Poor: Energy and Development Report 2000, P. J. Brook and S. Smith, Eds. Washington: ESMAP, World Bank, 2000, pp. 92-99.

[16] R. Bailis, C. Kirubi, and A. Jacobson, "Searching for Sustainability: Kenya's Energy Past and Future," African Centre for Technology Studies., Nairobi, 2006.

[17] M. Hankins, A. Saini, and P. Kirai, "Kenya's Solar Energy Market: Target Market Analysis," Deutsche Gesellschaft für Technische Zusammenarbeit (GTZ), Berlin, 2009.

[18] M. Moner-Girona, R. Ghanadan, A. Jacobson, and D. M. Kammen, "Decreasing PV Costs in Africa: Opportunities for Rural Electrification using Solar PV in Sub-Saharan Africa," Refocus, vol. 7, no. 1, pp. 40-45, 2006.

[19] J. Ondraczek, "The sun rises in the east (of Africa): a comparison of the development and status of solar energy markets in Kenya and Tanzania," Energy Policy, vol. 56, pp. 407-417, May 2013.

[20] J. Ondraczek, "Are we there yet? Improving solar PV economics and power planning in developing countries: The case of Kenya," Renew. Sustain. Energy Rev., vol. 30, pp. 604-615, Feb. 2014.

[21] Ramboll, "Renewable energy resource potential in Kenya," Consultancy report prepared for the Minstry of Energy in Kenya., 2012.

[22] E. Meza, "Special Report Africa: Kenya," PV-Magazine, 2013. [Online]. Available: http://www.pv-magazine.com/news/details/beitrag/special-report-africa-kenya_100013508/\#axzz2yN8PFzyz. [Accessed: 19-Feb-2015].

[23] C. Muchunku, "Solar PV Market in Kenya: Status and Opportunities," BSW-Solar Special Exhibit Rural Electrification Intersolar 2013, Munich, Germany., 2013.

[24] M. Hankins, "Minigrid Policy Toolkit. Mini-Grids Opportunities for Rural Development in Africa," AEI Workshop Arusha, 5. September, 2013, 2013.

[25] G. Hille and M. Franz, "Grid Connection of Solar PV Technical and Economical Assessment of Net-Metering in Kenya," Deutsche Gesellschaft für Technische Zusammenarbeit (GIZ)., Berlin, 2011.

[26] S. Mbogo, "Largest solar plant in EA to be opened in Kenya," The East African, 2013. [Online]. Available: http://www.theeastafrican.co.ke/business/Largest-solar-plant-in-EA-to-beopened-in-Kenya-/-/2560/1920704/-/1jjuo6/-/index.html. [Accessed: 17-Jun-2014].

[27] S. Abdullah and A. Markandya, "Rural electrification programmes in Kenya: policy conclusions from a valuation study," Energy Sustain. Dev., vol. 16, no. 1, pp. 103-110, Mar. 2012.

[28] I. P. Da Silva, G. Batte, J. Ondraczek, G. Ronoh, and C. A. Ouma, "Diffusion of solar energy technologies in rural Africa: trends in Kenya and the LUAV," Proc. from 1st Africa Photovolt. Sol. Energy Conf. Exhib. 27-29 March 2014, Durban, South Africa, vol. 1, no. March, pp. 2729, 2014. 
[29] M. Hankins, "Market potentials for German solar energy companies in East Africa.," Presentation at HannoverMesse, 22. April, 2009, 2009.

[30] R. P. Byrne, "Learning drivers: Rural electrification regime building in Kenya and Tanzania," PhD Thesis. University of Sussex, 2009.

[31] GoK, "Second Medium Term Plan 2013-2017. Transforming Kenya: pathway to devolution. socio-economic development and national utility," Government of Kenya (GoK), 2013.

[32] Government of Kenya, "National Energy Policy: third draft," Government of Kenya (GoK), 2012.

[33] H. Gichungi, “Mini grid PV business opportunities in Kenya,” Presentaion, 2013.

[34] GoK, "Scaling up Renewable Energy Program (SREP) investment plan for Kenya," Government of Kenya (GoK), 2011.

[35] University of Southampton, "Energy for Development (E4D): Community Progress within the First Year Operation of the Solar Rural Electrification Project in Kenya," Sustainable Energy Research Group [online], 2013. [Online]. Available: http://www.energy.soton.ac.uk/e4d-firstyear-operation/. [Accessed: 18-Jun-2014].

[36] ME, "Feed-in-tariffs policy on wind, biomass, small-hydro, geothermal, biogas and solar resource generated electricity," Ministry of Energy (ME) Kenya, Nairobi, 2012.

[37] B. Willis, "Kenya's FiT-approved solar pipeline reaches 750MW," PV-Tech, 2014. [Online]. Available: http://www.pvtech.org/news/kenyas_fit_approved_solar_pipeline_reaches_750mw. [Accessed: 18-Jun2014].

[38] A. Finkelstein, "Kenya Getting One of Largest Grid-Connected Solar Power Plants in Africa," 2012. [Online]. Available: http://www.worldpropertychannel.com/middle-east-africacommercial-news/jinkosolar-cooperate-kenya-solar-power-plant-china-jiangxi-corporationfor-international-economic-technical-co-Itd-guojian-xu-new-solar-farms-6162.php. [Accessed: 27-Jun-2014].

[39] L. Woods, "MoU agreed for 50MW Kenya PV project," PV Tech, 2013. [Online]. Available: http://www.pv-tech.org/news/kenya_signs_mou_for_50mw_with_canadian_consortium. [Accessed: 16-Feb-2015].

[40] M. Hankins, A. Saini, and P. Kirai, "Tanzania's Solar Energy Market: Target Market Analysis," Deutsche Gesellschaft für Technische Zusammenarbeit (GTZ)., Berlin, 2009.

[41] E. Meza, "Special Report Africa: Tanzania, Mozambique," PV-Magazine, 2013. [Online]. Available: http://www.pv-magazine.com/news/details/beitrag/special-report-africa-tanzania--mozambique_100013524/\#axzz30s1BdeuY. [Accessed: 17-Jun-2014].

[42] A. E. M. Bleeker, "Diffusion of Solar PV from a TIS perspective \& its transnational factors. A case study of Tanzania.," Thesis. University of Amsterdam, 2013. 
[43] G. M. J. Nchwali, "Rural Electrification Context in Tanzania," Presented at: 7th Annual Meeting of the Club of African Agencies and Structures in charge of Rural Electrification (ERCLUB) 23 - 26 March 2010, Mombasa, 2010.

[44] CAMCO, "Solar photovoltaic (PV) Clusters Project in Tanzania," 30-Apr-2014. [Online]. Available: http://www.camcocleanenergy.com/sidamemsolarpvprojectafrica.html. [Accessed: 06-May-2014].

[45] UNEP, "Tanzania: Transformation of the Rural Photovoltaic Market in Tanzania," UNEP Succes Stories Leads [online], 2014. [Online]. Available: http://web.undp.org/comtoolkit/successstories/AFRICA-Tanzania-energyenviron.shtml. [Accessed: 06-May-2014].

[46] D. Bauner, M. Sundell, J. Senyahwa, and J. Doyle, "Sustainable Energy Markets in Tanzania Report I: Background," Stockholm Environment Institute, Stockholm, 2012.

[47] World Bank, "Gef Project Brief On A Proposed Grant From The Global Environment Facility Trust Fund In The Amount Of Usd 6.5 Million To The United Republic Of Tanzania For An Energizing Rural Transformation Project," World Bank, Washington DC, 2006.

[48] GoT, "Scaling-up Renewable Energy Programme (SREP) investment plan for Tanzania," Government of Tanzania (GoT), 2013.

[49] B. Tenenbaum, C. Greacen, T. Siyambalapitiya, and J. Knuckles, "From the Bottom Up: How Small Power Producers and Mini-Grids Can Deliver Electrification and Renewable Energy in Africa," World Bank, Washington DC, 2014.

[50] Rural Energy Agency, "LRTC2014 Grant Award Competition Winners," The United Republic of Tanzania, Ministry of Energy and Minerals, 2014.

[51] J. Nganga, M. Wohlert, M. Woods, C. Becker-Birk, S. Jackson, and W. Rickerson, "Powering Africa through Feed-in Tariffs: Advancing Renewable Energy to Meet the Continent's Electricity Needs.," World Future Council, the Heinrich Böll Stiftung, Friends of Earth England, Johannesburg, 2013.

[52] GTZ, "Eastern Africa Resource Base: GTZ Online Regional Energy Resource Base: Regional and Country Specific Energy Resource Database: II - Energy Resource.," 2007.

[53] M. Hankins, A. Saini, and P. Kirai, "Uganda's Solar Energy Market. Target Market analysis," Deutsche Gesellschaft für Technische Zusammenarbeit (GTZ)., Berlin, 2009.

[54] P. Eliah, E., Louineau, "Here comes the sun: the hope of rural electrification in Uganda relies on solar energy," Gate Technology and Development, No. 1 - Small Scale Fisheries. GTZ, 1999.

[55] E. Mark, "Assessing the use of power generation technologies in Uganda: a case study of Jinja Municipality," PhD Thesis. Stockholm University., 2012.

[56] J. Baanabe, "Energy supply in uganda.," Presentation by James Baanabe, Ministry of Energy and Mineral Resources Uganda. National Workshop on promoting Sustainable Transport Solutions for East Africa, 1 August, 2012, 2012. 
[57] M. Kakooza, E. Begumisa, F. Dold, and S. Wassler, "Solar Market Development study i nUganda," Centre for Research in Energy and Energy Conservation (CREEC), College of Engineering, Design, Art and Technology Makerere University, Kampala, Uganda, 2014.

[58] D. Brandt, "AC Mini-Grids. The future of Community-Scale Renewable Energy," Home Power 109, October \& November, pp. 48-54, 2005.

[59] World Bank, "Uganda: Energy for Rural Transformation," The World Bank, 2014. [Online]. Available: http://www.worldbank.org/projects/P112334/uganda-energy-ruraltransformation-apl-2?lang=en\&tab=overview. [Accessed: 18-Jun-2014].

[60] GoU, "The Government of the Republic of Uganda: Rural Electrification Strategy and Plan, Covering the Period 2013-2022," Government of Uganda (GoU), 2012.

[61] UNDP, "Uganda-UPPPRE Terminal Evaluation Report: Draft 2 3/10/2002," United Nations Development Programme (UNDP) and Global Environment Facility (GEF)., 2002.

[62] REA, “Annual Report 2008/09.," Rural Electrification Agency (REA) Uganda., 2008.

[63] European Commision, "Development and Cooperation - EUROPEAID: Modernising energy use in Northern Uganda," 2014. [Online]. Available:

http://ec.europa.eu/europeaid/what/energy/sustainable/panemu_en.htm. [Accessed: 17Jun-2014].

[64] European Commision, "Thematic Fiche no. 5: Solar PV for Improving Rural Access to Electricity," The ACP-EU Energy Facility, Bruxelles, 2011.

[65] GIZ, "Mobile Phone Masts as Beacons of Rural Electrification: pilot project for solar energy supply in off-grid regions," Flyer on private sector cooperation. Deutsche Gesellschaft für Technische Zusammenarbeit (GIZ), 2013.

[66] J. Parnell, "Ugandan government signs deal for 500MW of solar power," PV-Tech, 2013. [Online]. Available: http://www.pvtech.org/news/ugandan_government_signs_deal_for_500mw_of_solar_power. [Accessed: 18-Jun-2014].

[67] I. Tsagas, "Uganda drops PV FIT program," PV-Magazine [online], 2013. [Online]. Available: http://www.pv-magazine.com/news/details/beitrag/uganda-drops-pv-fitprogram_100010696/\#axzz317UYTnrF. [Accessed: 18-Jun-2014].

[68] GET FIT Uganda, "GET FIT Solar Facility," 2014. [Online]. Available: http://www.getfituganda.org/about-get-fit/get-fit-solar-facility/. [Accessed: 17-Jun-2014].

[69] M. Gullberg, E. Ilskog, M. Katyega, and B. Kjellström, "Village electrification technologies - an evaluation of photovoltaic cells and compact fluorescent lamps and their applicability in rural villages based on a Tanzanian case study," Energy Policy, vol. 33, no. 10, pp. 1287-1298, Jul. 2005.

[70] S. Twaha, M. H. Idris, M. Anwari, and A. Khairuddin, "Applying grid-connected photovoltaic system as alternative source of electricity to supplement hydro power instead of using diesel in Uganda," Energy, vol. 37, no. 1, pp. 185-194, Jan. 2012. 
[71] R. T. Kivaisi, "Installation and use of a $3 \mathrm{~kW} \mathrm{p} \mathrm{PV} \mathrm{plant} \mathrm{at} \mathrm{Umbuji} \mathrm{village} \mathrm{in} \mathrm{Zanzibar,"} \mathrm{Renew.}$ Energy, vol. 19, pp. 457-472, 2000.

[72] J. R. Hogarth, "Promoting diffusion of solar lanterns through microfinance and carbon finance: a case study of FINCA-Uganda's solar loan programme," Energy Sustain. Dev., vol. 16, no. 4, pp. 430-438, Dec. 2012.

[73] S. Bawakyillenuo, "Deconstructing the dichotomies of solar photovoltaic (PV) dissemination trajectories in Ghana, Kenya and Zimbabwe from the 1960s to 2007," Energy Policy, vol. 49, pp. 410-421, Oct. 2012.

[74] A. E. Jacobson, "Connective Power: Solar Electrification and Social Change in Kenya," PhD Thesis. University of California, Berkeley., 2004.

[75] G. R. Kassenga, "The Status and Constraints of Solar Photovoltaic Energy Development in Tanzania," Energy Sources, Part B Econ. Planning, Policy, vol. 3, no. 4, pp. 420-432, Sep. 2008.

[76] J. Lay, J. Ondraczek, and J. Stoever, "Renewables in the energy transition: evidence on solar home systems and lighting fuel choice in Kenya," Energy Econ., vol. 40, pp. 350-359, Nov. 2013. 